\title{
PENGARUH PAJAK DAERAH DAN RETRIBUSI DAERAH TERHADAP PENDAPATAN ASLI DAERAH (PAD)
}

(Studi Kasus pada Pemerintah Daerah Kota Bandung periode 2011-2015)

\section{Regina Usman}

$\underline{1 \text { regianusman@students.telkomuniversity.ac.id, }}$

\begin{abstract}
Local revenu (PAD) is a local earned revenue collected by the regional regulation in accordance with the legislation. Sources of revenue are derived from local tax, local retribution, regional owned enterprises and local wealth management results, and other revenues. The more the local needs can be financed by PAD, the higher the quality of the local autonomy.

This study aims to determine the influence of local tax and local retribution to local revenue of Bandung period of 2011-2015 either simultaneously or partially.

The population in this study is a Realized Regional Government Budget Report of Bandung in 2011-2015. Sample selection technique used is judgment sampling and obtained 60 samples, consisting of January to December 2011-2015. The data analysis method was multiple regression analysis.

The results show that there is simultaneous significant difference between local tax and local retribution to local revenue. Partially, local tax has significant positive effect on PAD, while the local retribution has no significant effect on $P A D$.
\end{abstract}

Keywords : Local Tax, Local Retribution, Local Revenue 


\section{PENDAHULUAN}

Indonesia merupakan negara kesatuan yang menganut asas desentralisasi dalam penyelenggaraan pemerintahan dengan memberikan kesempatan dan keleluasaan kepada daerah untuk menyelenggarakan otonomi daerah, sebagaimana yang dijelaskan dalam Undang-Undang Nomor 32 Tahun 2004 tentang Pemerintah Daerah. Munculnya Undang-Undang Nomor 12 Tahun 2008 tentang perubahan kedua atas Undang-Undang Nomor 32 Tahun 2004 tentang Pemerintahan Daerah membawa perubahan yang begitu besar bagi pelaksanaan pembangunan daerah. Secara tegas undang-undang ini memberikan kewenangan kepada daerah untuk mengatur dan mengurus kepentingan masyarakat setempat menurut prakarsa sendiri berdasarkan aspirasi masyarakat atau dengan kata lain berdasarkan Undang-Undang Nomor 12 Tahun 2008 daerah telah diberikan kewenangan untuk melaksanakan otonomi daerah. Sumber keuangan daerah dalam pelaksanaan desentralisasi terdiri atas pendapatan daerah dan pembiayaan daerah. Sumber keuangan daerah yang bersumber dari pendapatan daerah diantaranya yaitu Pendapatan Asli Daerah (PAD), dana perimbangan dan lain-lain pendapatan. Sumber keuangan daerah yang fundamental, dimiliki dan dikelola oleh pemerintah daerah adalah Pendapatan Asli Daerah (PAD). Pendapatan Asli Daerah (PAD) merupakan penerimaan yang berasal dari daerah sendiri yang terdiri dari hasil pajak daerah, hasil retribusi daerah, hasil perusahaan milik daerah dan hasil pengelolaan kekayaan daerah yang dipisahkan, dan lain-lain pendapatan asli daerah yang sah. Optimalisasi PAD diharapkan dapat menjadi penyangga dalam penyelenggaraan kegiatan pemerintah daerah, semakin banyak kebutuhan daerah yang dapat dibiayai oleh PAD maka semakin tinggi pula tingkat kualitas otonomi daerah, sehingga daerah tersebut semakin mandiri dalam bidang keuangannya.

Berdasarkan laporan realisasi penerimaan Kota Bandung, PAD Kota Bandung selalu meningkat selama lima tahun terakhir. Namun hal tersebut berbanding terbalik dengan persentase capaian PAD yang selama lima tahun terakhir selalu menurun. Hal ini bisa dilihat pada grafik 1.1 berikut: 


\section{Grafik 1 Persentase Capaian PAD Kota Bandung Tahun 2011-2015}

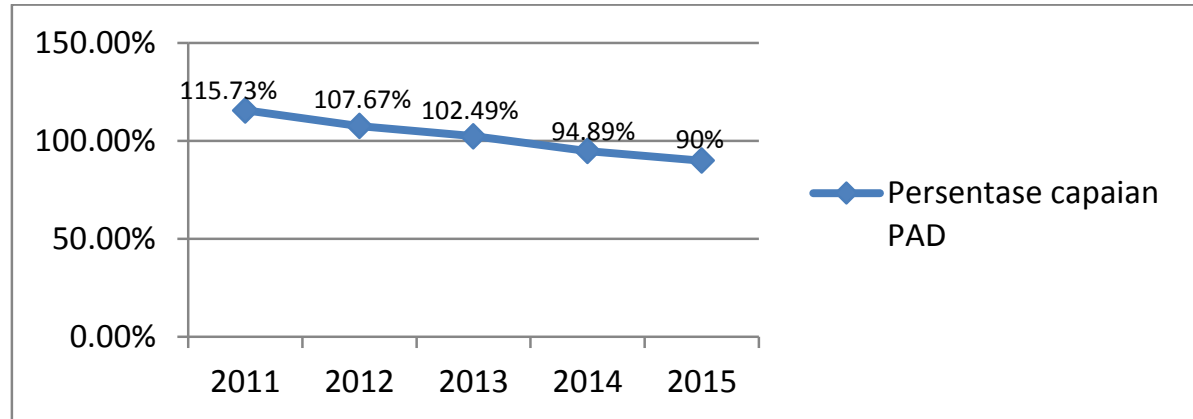

Sumber: Dinas Pengelolaan Keuangan dan Aset Daerah Kota Bandung

Berdasarkan grafik 1.1 dapat dilihat bahwa laju persentase capaian PAD Kota Bandung setiap tahunnya selalu mengalami penurunan, terutama untuk tahun 2014 dan 2015 yang kurang dari 100\%, hal ini disebabkan masih kurang optimalnya pemungutan dari sumber-sumber PAD itu sendiri, sehingga menyebabkan realisasi PAD yang ada tidak dapat mencapai target yang telah ditetapkan. Jika PAD Kota Bandung tidak dapat mencapai target yang telah ditetapkan, maka pembangunan infastruktur yang telah direncanakan Kota Bandung akan sedikit terhambat. Pembangunan infrastruktur menjadi salah satu kunci peningkatan pertumbuhan ekonomi yang berkesinambungan.

Pajak daerah dan retribusi daerah mempunyai peranan dan kontribusi paling besar terhadap PAD, dimana pengelolaannya diserahkan kepada derah itu sendiri dan dalam menyelenggarakan pembangunan di daerahnya, faktor sumber pendapatan pajak daerah dan retribusi daerah sangat menentukan terlaksananya pembangunan itu sendiri

Pajak daerah yang seharusnya menjadi sumber Pendapatan Asli Daerah (PAD) yang tinggi pada tahun 2015 realisasinya hanya memberikan kontribusi sebesar 92,94\% dari Rp. 2.066.246.830.526 target yang telah ditetapkan. Hal ini karena beberapa jenis pajak daerah seperti pajak hotel, pajak hiburan, pajak penerangan jalan, pajak parkir, PBB dan BPHTB yang diperoleh masih dibawah $100 \%$. Sebagai contoh untuk pajak hotel, berdasarkan survei yang dilakukan oleh Perhimpunan Hotel dan Restoran Indonesia (PHRI) saat ini terdapat 406 hotel dengan berbagai klasifikasi yang tersebar di kota Bandung. Banyaknya hotel di 
Kota Bandung dikarenakan mudahnya izin yang didapatkan dari Pemerintah Kota Bandung, hal ini seharusnya berdampak pada penerimaan pajak hotel di Kota Bandung. Berdasarkan Undang-Undang Nomor 28 Tahun 2009, pajak hotel merupakan pajak atas pelayanan yang disediakan oleh hotel. Dari total 406 hotel tersebut hanya 362 hotel yang ditarik pajaknya. Selain itu, banyak dari hotel berbintang dan hotel mewah yang menunggak membayar pajaknya, sehingga hal ini lah yang menyebabkan tidak tercapainya target penerimaan pajak hotel. Contoh lain yaitu untuk pajak hiburan, Kota Bandung merupakan kota yang mempunyai berbagai macam hiburan yang seharusnya meningkatkan jumlah penerimaan pajak hiburan. Namun hal tersebut bisa terhambat dengan dikeluarkannya peraturan pembatasan jam malam pada awal tahun 2014 lalu. Dimana Pemerintah Kota Bandung menetapkan bahwa semua aktivitas dan kegiatan hiburan di Kota Bandung dilarang beroperasi melebihi pukul 12 malam. Sehingga peraturan tersebut membuat menurunnya penerimaan pajak hiburan serta tidak tercapainya target yang telah ditetapkan (Dudi, Bagian Akuntansi DPKAD Kota Bandung).

Retribusi daerah yang juga seharusnya menjadi sumber PAD yang tinggi pada realisasinya hanya memberikan kontribusi sebesar 59,13\% dari Rp. 107.563.238.797 target yang telah ditetapkan. Hal tersebut karena ada beberapa jenis retribusi perizinan tertentu seperti retribusi izin mendirikan bangunan, izin gangguan tempat usaha/kegiatan kepada orang pribadi, retribusi izin trayek kepada orang pribadi dan retribusi izin trayek kepada badan yang diperoleh masih dibawah $100 \%$. Sebagai contoh untuk retribusi izin mendirikan bangunan, dimana di Kota Bandung hampir setiap tahunnya banyak didirikan bangunan-bangunan besar seperti apartement, hotel dan penginapan sehingga seharusnya hal tersebut akan berdampak pada peningkatan penerimaan retribusi izin mendirikan bangunan. Namun pada awal tahun 2015 Pemerintah Kota Bandung mengeluarkan peraturan baru yaitu membatasi pembangunan di daerah Bandung Utara yang merupakan tempat favorit bagi investor untuk mendirikan bangunan. Hal tersebut menjadi salah satu penyebab tidak tercapainya penerimaan retribusi Izin Mendirikan Bangunan (IMB) di Kota Bandung Tahun 2015. Sejalan dengan 
dikeluarkannya peraturan untuk membatasi pembangunan tersebut membuat penerimaan retribusi izin gangguan tempat usaha juga akan berkurang, karena retribusi IMB sangat erat kaitannya dengan retribusi izin gangguan usaha. Sehingga hal tersebut juga membuat tidak tercapainya penerimaan retribusi izin gangguan usaha di Kota Bandung pada tahun 2015 (Ganjar, Bagian Keuangan dan Program BPPT Kota Bandung).

Tujuan penelitian ini adalah untuk mengetahui seberapa besar pajak daerah, retribusi daerah dan Pendapatan Asli Daerah (PAD) Kota Bandung tahun 20112015, serta mengetahui pengaruh pajak daerah dan retribusi daerah terhadap pendapatan asli daerah baik secara simultan maupun parsial. Populasi dalam penelitian ini adalah Laporan Realisasi APBD Kota Bandung tahun anggaran 2011-2015. Teknik sampel yang digunakan dalam penelitian ini adalah judgement sampling. Pada jenis ini sampel dipilih berdasarkan penilaian peneliti bahwa data tersebut adalah pihak yang paling baik untuk dijadikan sampel penenelitian (Darmawan, 2013: 152). Sehingga diperoleh 60 sampel terdiri dari bulan Januari sampai Desember tahun 2011-2015. Teknik analisis yang digunakan dalam penelitian ini menggunakan analisis statistik deskriptif dan regresi berganda.

\section{DASAR TEORI DAN METODOLOGI}

\section{Dasar Teori}

\section{Pajak Daerah}

Menurut Mardiasmo (2016:14) pajak daerah adalah iuran wajib yang dilakukan oleh orang pribadi atau badan kepada daerah tanpa imbalan langsung yang seimbang, yang dapat dipaksakan berdasarkan peraturan perundang-undangan yang berlaku, yang digunakan untuk membiyai penyelenggaraan pemerintah daerah dan pembangunan daerah. Jenis-jenis pajak daerah diantaranya pajak hotel, pajak restoran, pajak hiburan, pajak reklame, pajak penerangan jalan, pajak mineral bukan logam dan batuan, pajak sarang burung walet, pajak parkir, pajak air tanah, pajak bea perolehan hak tanah dan bangunan, dan pajak Bumi dan bangunan pedesaan dan perkotaan 


\section{Retribusi Daerah}

Menurut Undang-Undang 28 Tahun 2009 mengenai Pajak Daerah dan Retribusi Daerah, retribusi daerah adalah pungutan daerah sebagai pembayaran atas jasa atau pemberian izin tertentu yang khusus disediakan dan/atau diberikan oleh pemerintah daerah untuk kepentingan orang pribadi atau badan.Retribusi daerah dibagi menjadi tiga jenis yaitu retribusi jasa umum, retribusi jasa usaha dan retribusi perizinan tertentu.

\section{Pendapatan Asli Daerah}

Berdasarkan Undang-Undang Nomor 33 Tahun 2004 menyatakan bahwa Pendapatan Asli Daerah yang disingkat PAD adalah pendapatan yang diperoleh daerah yang dipungut berdasarkan Peraturan Daerah sesuai dengan peraturan perundang-undangan. Sumber-sumber pendapatan asli daerah yaitu pajak daerah, retribusi daerah, hasil pengelolaan kekayaan daeah yang dipisahkan dan lain-lain PAD yang sah.

\section{Pengaruh Pajak Daerah terhadap Pendapatan Asli Daerah}

Pajak daerah merupakan salah satu sumber pendapatan daerah yang sangat penting untuk membiayai penyelenggaraan pemerintahan dan pembangunan daerah. Selain itu pajak daerah merupakan bentuk peran serta masyarakat dalam menyelenggarakan otonomi daerah. Pajak daerah juga merupakan salah satu sumber pendapatan asli daerah, dimana setiap peningkatan pajak daerah akan mempengaruhi peningkatan pada pendapatan asli daerah. Dengan demikian, adanya hubungan antara pajak daerah dengan pendapatan asli daerah yaitu jika jumlah penerimaan pajak daerah mengalami kenaikan maka pendapatan asli daerah juga mengalami kenaikan

\section{Pengaruh Retribusi Daerah terhadap Pendapatan Asli Daerah}

Retribusi daerah merupakan salah satu komponen PAD yang mempunyai peranan cukup besar terhadap pelaksanaan otonomi daerah untuk merealisasi pendapatan asli daerah. Daerah mempunyai kewenangan dalam memungut semua 
jenis retribusi daerahnya. Peran serta masyarakat dalam membayar retribusi sangat diharapkan untuk meningkatkan penerimaan retribusi daerah. Semakin besar jumlah penerimaan retribusi daerah maka akan semakin besar pula jumlah penerimaan pendapatan asli daerah. Dengan demikian, adanya hubungan antara retribusi daerah dengan pendapatan asli daerah yaitu jika jumlah penerimaan retribusi daerah mengalami kenaikan maka pendapatan asli daerah juga mengalami kenaikan.

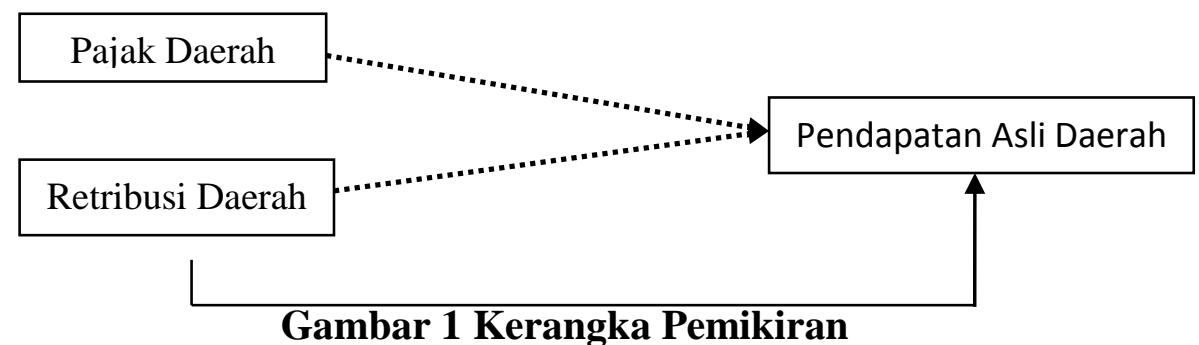

Keterangan:

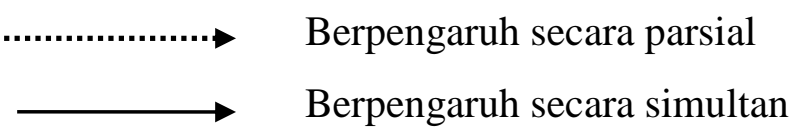

\section{Metodologi Penelitian}

Populasi dalam penelitian ini adalah Laporan Realisasi APBD Kota Bandung tahun anggaran 2011-2015. Teknik sampel yang digunakan dalam penelitian ini adalah judgement sampling, sehingga diperoleh 60 sampel terdiri dari bulan Januari sampai Desember tahun 2011-2015. Model regresi linier berganda dapat dinyatakan dalam persamaan matematis sebagai berikut :

$$
\mathrm{Y}=\mathrm{a}+\mathrm{b}_{1} \mathrm{X}_{1}+\mathrm{b}_{2} \mathrm{X}_{2}+\mathrm{e}
$$

Keterangan :

$\mathrm{Y}=$ Pendapatan Asli Daerah

$\mathrm{a}=$ Konstanta

$\mathrm{X}_{1}=$ Pajak Daerah

$\mathrm{X}_{2}=$ Retribusi Daerah

$\mathrm{b}_{1}=$ Koefisien Pajak Daerah

$\mathrm{b}_{2}=$ Koefisien Retribusi Daerah

e = Kesalahan/eror 


\section{PEMBAHASAN}

\section{Statistik Deskriprif}

\section{Tabel 1 Statistik Deskriptif}

Descriptive Statistics

\begin{tabular}{|l|r|c|r|r|r|}
\hline & $\mathrm{N}$ & Minimum & Maximum & \multicolumn{1}{c|}{ Mean } & \multicolumn{1}{c|}{ Std. Deviation } \\
\hline PajakDaerah & 60 & 18.355 .892 .992 & 280.235 .744 .46 & $92.925 .069 .063,0667$ & $46.431 .730 .626,60630$ \\
RetribusiDaerah & 60 & 3.474 .187 .471 & 18.992 .272 .737 & $7.577 .157 .930,2167$ & $3.367 .170 .194,93370$ \\
PAD & 60 & 30.055 .475 .023 & 309.057 .283 .82 & & \\
& & & & & \\
Valid N (listwise) & 60 & & & & \\
\hline
\end{tabular}

Sumber: Hasil pengolahan data dengan SPSS 23

Berdasarkan uji statsitik deskriprif pada tabel diapat diperoleh informasi bahwa pajak daerah selama lima tahun terakhir memiliki nilai minimum sebesar Rp. 18.355.892.992 terjadi pada bulan Januari tahun 2011 dan nilai maximum sebesar Rp. 280.235.744.468 terjadi pada bulan September tahun 2015. Sedangkan ratarata penerimaan pajak daerah dari tahun 2011 hingga tahun 2015 adalah sebesar Rp. 92.925.069.063,06. Standar deviasi yang diperoleh sebesar Rp. 46.431.730.626,60. Sementara nilai minimum retribusi daerah diperoleh sebesar Rp. 3.474.187.471 terjadi pada bulan Juli tahun 2015 dan nilai maximum terjadi pada bulan Mei tahun 2014 sebesar Rp. 18.992.272.737. Sedangkan rata-rata penerimaan retribusi daerah dari tahun 2011 hingga tahun 2015 adalah sebesar Rp.7.577.157.930,21. Standar deviasi yang diperoleh sebesar Rp.3.367.170.194,93. Nilai minimum PAD selama lima tahun terakhir sebesar Rp. 30.055.475.023 terjadi pada bulan Januari tahun 2011 dan nilai maximum PAD sebesar Rp. 309.057.283.822 terjadi pada bulan Agustus tahun 2015. Sementara rata-rata penerimaan PAD selama tahun 2011 sampai tahun 2015 adalah sebesar Rp. 114.289.412.998,71. Standar deviasi yang diperoleh sebesar Rp. $55.244 .526 .111,32$.

\section{Uji Asumsi Klasik}


Menurut Sanusi (2011:135) regresi linier berganda harus memenuhi asumsiasumsi yang ditetapkan agar menghasilkan nilai-nilai koefisien sebagai penduga yang tidak bias. Berikut hasil uji asumsi klasik:

\section{Uji Normalitas}

Tabel 2 Uji Normalitas

One-Sample Kolmogorov-Smirno Test

\begin{tabular}{|ll|r|}
\hline & & $\begin{array}{c}\text { Unstandardized } \\
\text { Residual }\end{array}$ \\
\hline $\mathrm{N}$ & Mean & 60 \\
Normal & Std. &, 0000000 \\
Parameters & a,b &, 07828786 \\
Most Extreme & Absolute &, 111 \\
Differences & Positive &, 111 \\
& Negative &,- 099 \\
Test Statistic & &, 111 \\
Asymp. Sig. (2-tailed) &, $062^{c}$ \\
\hline
\end{tabular}

a. Test distribution is Normal.

b. Calculated from data.

c. Lilliefors Significance Correction.

Sumber : Hasil pengolahan data dengan

SPSS 23 
Berdasarkan uji yang dilakukan dengan Kolmogrov Smirnov, diperoleh nilai signifikansi 0,062. Hal ini menunjukkan bahwa nilai signifikasi lebih besar daripada 0,05 sehingga data berdistribusi normal.

\section{Uji Heteroskedastisitas}

\section{Grafik 2 Uji Heteroskedastisitas}

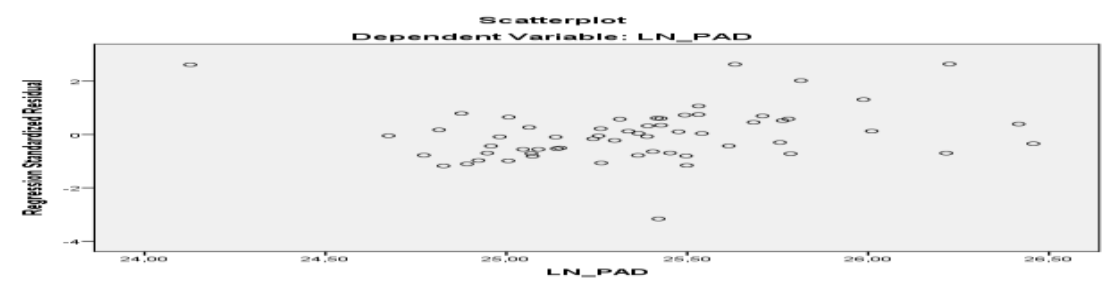

Sumber : Hasil pengolahan data dengan SPSS 23

Berdasarkan uji yang dilakukan dengan menggunakan grafik Scatter plot, dapat disimpulkan bahwa titik-titik menyebar secara acak serta tersebar diatas dan dibawah angka nol pada sumbu Y. Dapat disimpulkan bahwa tidak terjadi heteroskedastisitas pada model regresi ini.

\section{Uji Autokorelasi}

Tabel 3 Uji Autokorelasi

Model Summary

\begin{tabular}{|l|r|r|r|r|r|}
\hline Model & $\mathrm{R}$ & R Square & $\begin{array}{c}\text { Adjusted } \\
\text { R Square }\end{array}$ & $\begin{array}{c}\text { Std. Error } \\
\text { of the } \\
\text { Estimate }\end{array}$ & $\begin{array}{c}\text { Durbin- } \\
\text { Watson }\end{array}$ \\
\hline 1 &, $983^{\mathrm{a}}$ &, 967 &, 966 &, 07965 & 1,637 \\
\hline
\end{tabular}

a. Predictors: (Constant), LN_RetribusiDaerah, LN_PajakDaerah

b. Dependent Variable: LN_PAD

Sumber : Hasil pengolahan data dengan SPSS 23

Berdasarkan uji yang dilakukan dengan menggunakan Durbin-Watson (d), sebesar 1,637 sehingga tidak terjadi autokorelasi karena angka Durbin Waston berada pada nilai -2 sampai +2 . Model regresi yang baik adalah jika regresi bebas dari autokorelasi 


\section{Uji Multikolinieritas}

Tabel 4 Uji Multikolinearitas

Coefficients $^{\mathrm{a}}$

\begin{tabular}{|c|c|c|c|c|c|c|c|}
\hline \multirow[b]{2}{*}{ Model } & \multicolumn{2}{|c|}{$\begin{array}{c}\text { Unstandardized } \\
\text { Coefficients }\end{array}$} & $\begin{array}{l}\text { Standardize } \\
\text { d } \\
\text { Coefficients }\end{array}$ & \multirow[b]{2}{*}{$\mathrm{T}$} & \multirow[b]{2}{*}{ Sig. } & \multicolumn{2}{|c|}{$\begin{array}{l}\text { Collinearity } \\
\text { Statistics }\end{array}$} \\
\hline & B & $\begin{array}{l}\text { Std. } \\
\text { Error }\end{array}$ & Beta & & & $\begin{array}{c}\text { Toleranc } \\
\mathrm{e}\end{array}$ & VIF \\
\hline $1 \quad$ (Constant) & ,827 & ,757 & & 1,091 & ,280 & & \\
\hline LN_PajakDaerah & ,946 & ,024 & ,977 & 39,837 & ,000 & ,962 & 1,039 \\
\hline $\begin{array}{l}\text { LN_RetribusiDaera } \\
\mathrm{h}\end{array}$ & ,033 & ,026 & ,031 & 1,249 & ,217 & ,962 & 1,039 \\
\hline
\end{tabular}

a. Dependent Variable: LN_PAD

Sumber: Hasil pengolahan data dengan SPSS 23

Berdasarkan uji yang dilakukan dengan melihat nilai VIF dari hasil analisis regresi, nilai Variance Inflating Factor (VIF) pada variabel pajak daerah dan retribusi daerah kurang dari 10, dan nilai tolerance besar dari 0,10. Maka dalam pengujian ini tidak terjadi gelaja multikolinearitas. Sehingga tidak terjadi korelasi diantara variabel independen.

\section{Analisis Regresi Berganda}

Tabel 5 Hasil Analisis Regresi Berganda

Coefficients $^{\mathrm{a}}$

\begin{tabular}{|c|c|c|c|c|c|}
\hline \multirow[b]{2}{*}{ Model } & \multicolumn{2}{|c|}{$\begin{array}{l}\text { Unstandardized } \\
\text { Coefficients }\end{array}$} & \multirow{2}{*}{$\begin{array}{c}\begin{array}{c}\text { Standardized } \\
\text { Coefficients }\end{array} \\
\text { Beta }\end{array}$} & \multirow[b]{2}{*}{$\mathrm{t}$} & \multirow[b]{2}{*}{ Sig. } \\
\hline & B & $\begin{array}{l}\text { Std. } \\
\text { Error }\end{array}$ & & & \\
\hline $\begin{array}{ll}1 & \text { (Constant) }\end{array}$ & ,827 & ,757 & & 1,091 & ,280 \\
\hline LN_PajakDaerah & ,946 & ,024 & ,977 & 39,837 &, 000 \\
\hline LN_RetribusiDaerah & ,033 & ,026 & ,031 & 1,249 & ,217 \\
\hline
\end{tabular}

a. Dependent Variable: LN_PAD

Sumber: Hasil pengolahan data dengan SPSS 23 
Analisis regresi berganda adalah analisis yang menggambarkan hubungan antara tiga variabel atau lebih yaitu sekurang-kurangnya 2 variabel independen dan satu variabel dependen. Model regresi yang diperoleh adalah sebagai berikut:

$$
\mathrm{Y}=0,827+0,946 \mathrm{X}_{1}+0,033 \mathrm{X}_{2}+\varepsilon
$$

Dimana :

$\mathrm{Y} \quad=$ Pendapatan Asli Daerah

$\mathrm{X}_{1} \quad=$ Pajak Daerah

$\mathrm{X}_{2}=$ Retribusi Daerah

$\varepsilon \quad=$ Eror

Dari model regresi tersebut dapat disimpulkan sebagai berikut :

1. Nilai konstansta yang diporoleh adalah 0,827 menyatakan bahwa jika variabel independen pajak daerah dan retribusi daerah bernilai nol, diasumsikan bahwa jumlah pendapatan asli daerah yang diperoleh sebesar 0,827.

2. Koefisien regresi pajak daerah bernilai positif 0,946 menyatakan bahwa setiap kenaikan satu satuan pajak daerah maka diperkirakan pendapatan asli daerah akan meningkat sebesar 0,946 dengan asumsi bahwa variabel lain bernilai tetap.

3. Koefisien regresi retribusi daerah bernilai positif 0,033 menyatakan bahwa setiap kenaikan satu satuan retribusi daerah maka diperkirakan pendapatan asli daerah akan meningkat sebesar 0,033 dengan asumsi variabel lain bernilai tetap.

\section{Pengujian Hipotesis}

Uji hipotesis terdiri dari Koefisien determinasi, uji signifikansi simultan (uji statistik F), dan uji signifikansi parameter individual (uji statistik t). Berikut hasil pengujian hipotesis:

\section{Koefisien Determinasi}

Tabel 6 Koefisien Determinasi

Model Summary ${ }^{b}$

\begin{tabular}{|l|l|l|l|l|}
\hline Model & $\mathrm{R}$ & $\mathrm{R}$ & Adjusted & Std. Error of \\
\hline
\end{tabular}




\begin{tabular}{|c|c|c|c|c|}
\hline & & Square & $\begin{array}{c}\mathrm{R} \\
\text { Square }\end{array}$ & the Estimate \\
\hline 1 &, $983^{\mathrm{a}}$ & ,967 & ,966 & ,07965 \\
\hline
\end{tabular}

Sumber: Hasil pengolahan data dengan SPSS 23

Berdasarkan uji yang dilakukan dengan melihat nilai adjusted $R$ Square, nilai adjusted $R$ Square yang diperoleh sebesar 0,966. Nilai ini menyatakan bahwa sebesar 96,6\% perubahan pendapatan asli daerah Kota Bandung dipengaruhi oleh besarnya penerimaan pajak daerah dan retribusi daerah yang diperoleh, sedangkan sisanya sebesar $3,4 \%$ dipengaruhi oleh faktor-faktor lain diluar model.

\section{Pengujian Hipotesis secara Simultan (Uji F)}

Tabel 7 Uji signifikasi Simultan (Uji statistik F)

ANOVA $^{\mathrm{a}}$

\begin{tabular}{|l|r|r|l|l|l|}
\hline \multicolumn{1}{|l|}{ Model } & \multicolumn{1}{l|}{$\begin{array}{l}\text { Sum of } \\
\text { Squares }\end{array}$} & Df & Square & F & Sig. \\
\hline $1 \quad$ Regression & 10,602 & 2 & 5,301 & 835,613 &, $000^{\mathrm{b}}$ \\
& Residual & 57 &, 006 & & \\
Total & 10,964 & 59 & & & \\
\hline
\end{tabular}

a. Dependent Variable: LN_PAD

b. Predictors: (Constant), LN_RetribusiDaerah, LN_PajakDaerah

Sumber: Hasil pengolahan data dengan SPSS 23

Berdasarkan uji signifikansi simultan menghasilkan nilai signifikansi 0,000. Adapun nilai $\mathrm{F}$ tabel pada tingkat signifikansi adalah sebesar 3,16. Jika kedua nilai $\mathrm{F}$ ini dibandingkan, maka nilai $\mathrm{F}$ hitung yang diperoleh jauh lebih besar daripada $F$ tabel. Jika dilihat dari nilai signifikansi yang diperoleh yaitu sebesar $0,000<0,05$. Sehingga $\mathrm{H}_{\mathrm{a} 1}$ diterima, dan dapat disimpulkan pajak daerah dan retribusi daerah berpengaruh signifikan terhadap pendapatan asli daerah. Hasil tersebut konsisten dengan penelitian Ida Mentayani (2014) menunjukkan bahwa 
penerimaan pajak daerah dan retribusi daerah berpengaruh signifikan terhadap pendapatan asli daerah.

\section{Pengujian Hipotesis secara Parsial (Uji T)}

Tabel 4.8 Uji signifikasi Parsial (Uji statistik T)

Coefficients $^{\mathrm{a}}$

\begin{tabular}{|l|r|r|r|r|r|}
\hline & \multicolumn{2}{|c|}{$\begin{array}{c}\text { Unstandardized } \\
\text { Coefficients }\end{array}$} & $\begin{array}{c}\text { Standardized } \\
\text { Coefficients }\end{array}$ & & \\
\cline { 2 - 5 } Model & \multicolumn{1}{|c|}{$\mathrm{B}$} & Error & Beta & $\mathrm{t}$ & Sig. \\
\hline $1 \quad$ (Constant) &, 827 &, 757 & & 1,091 &, 280 \\
LN_PajakDaerah &, 946 &, 024 &, 977 & 39,837 &, 000 \\
LN_RetribusiDaerah &, 033 &, 026 &, 031 & 1,249 &, 217 \\
\hline
\end{tabular}

a. Dependent Variable: LN_PAD

Sumber: Hasil pengolahan data dengan SPSS 23

\section{Pengaruh Pajak Daerah terhadap Pendapatan Asli Daerah}

Variabel pajak daerah memiliki nilai t hitung 39,837. Jika dibandingkan dengan nilai t tabel yang hanya sebesar 2,00247, maka t hitung yang diperoleh jauh lebih besar dari t tabel. Hasil uji parsial menunjukkan nilai koefisien $\beta$ sebesar 0,946 dapat disimpulkan bahwa variabel pajak daerah mempunyai hubungan positif terhadap PAD. Jika dilihat dari nilai signifikansi yang diperoleh yaitu sebesar $0,000<0,05$. Sesuai dengan ketentuan pengambilan keputusan maka $\mathrm{H}_{\mathrm{a} 2}$ diterima yang berarti pajak daerah memiliki pengaruh signifikan terhadap PAD Kota Bandung secara parsial sehingga, semakin besar jumlah pajak daerah yang diterima maka akan semakin besar pula penerimaan pendapatan asli daerah Kota Bandung. Hasil tersebut konsisten dengan penelitian Fitriana (2014) dan Kusuma (2013) menunjukkan bahwa pajak daerah berpengaruh signifikan terhadap pendapatan asli daerah. 


\section{Pengaruh Retribusi Daerah terhadap Pendapatan Asli Daerah}

Variabel retribusi daerah memiliki nilai $\mathrm{t}$ hitung sebesar 1,247. Jika dibandingkan dengan t tabel sebesar 2,00247, maka nilai t hitung yang diperoleh lebih kecil daripada $\mathrm{t}$ tabel. Jika dilihat dari nilai signifikansi yang diperoleh yaitu sebesar 0,217 >0,05. Sesuai dengan ketentuan pengambilan keputusan maka $\mathrm{H}_{\mathrm{o} 3}$ diterima yang berarti retribusi daerah tidak memiliki pengaruh signifikan terhadap PAD Kota Bandung secara parsial, sehingga besar kecilnya penerimaan retribusi daerah belum tentu berpengaruh terhadap penerimaan pendapatan asli daerah Kota Bandung. Hasil penelitian ini konsisten dengan penelitian Krisna (2013) dan Lakoy (2016) bahwa tidak ada pengaruh yang signifikan dari retribusi daerah terhadap pendapatan asli daerah.

\section{KESIMPULAN DAN SARAN}

\section{Kesimpulan}

Hasil penelitian ini menunjukkan bahwa secara simultan pajak daerah dan retribusi daerah berpengaruh secara signifikan terhadap pendapatan asli daerah sebesar 96,6\%. Secara parsial pajak daerah berpengaruh signifikan secara positif terhadap pendapatan asli daerah, sementara retribusi daerah tidak berpengaruh secara signifikan terhadap pendapatan asli daerah.

\section{Saran}

1. Bagi masyarakat, diharapkan untuk meningkatkan kesadaran dalam membayar kewajiban pajak maupun retribusi daerahnya. Karena hasil dari komponen pendapatan asli daerah tersebut juga akan digunakan untuk kepentingan masyarakat seperti pembangunan infrastruktur daerah. Sehingga dengan semakin tinggi kesadaran masyarakat dalam membayar pajak dan retribusi berarti masyarakat ikut berkontribusi dalam membangun daerahnya serta 
berkontribusi dalam upaya meningkatkan kesejahteraan daerah tempat masyarakat tersebut berdomisili.

2. Bagi Pemerintah Kota Bandung diharapkan dapat menjadi bahan masukan dalam pelaksanaan pengelolaan keuangan daerah agar lebih meningkatkan pemungutan dan penerimaan dari masing-masing komponen pendapatan asli daerah terutama pajak daerah dan retribusi daerah, dengan cara meningkatkan pengawasan, pembinaan dan evaluasi terhadap pemungutan pajak dan retribusi daerah.

\section{Daftar Pustaka:}

[1] Darmawan, Deni. (2013). Metode Penelitian Kuantitatif (Cetakan Pertama). Bandung: Remaja Rosdakarya.

[2] Fitriana. (2014). Pengaruh pajak Daerah dan Retribusi Daerah dalam Meningkatkan Pendapatan Asli Daerah Kota Bontang. E-Jurnal Ilmu Pemerintahan. ISSN 2338-3651, Fakultas Ilmu Sosial dan Ilmu Politik. Universitas Mulawarman. Samarinda.

[3] Kusuma, Md. Krisna dan Ni Gst. Putu Wirawati. (2013). Analisis Pengaruh Penerimaan Pajak Daerah terhadap Peningkatan PAD Sekabupaten/Kota di Provinsi Bali. E-Jurnal Akuntansi. ISSN 23028556, Fakultas Ekonomi dan Bisnis. Universitas Udayana. Bali.

[4] Mardiasmo. (2016). Perpajakan Edisi Revisi. Penerbit Andi: Yogyakarta.

[5] Mentayani, Ida., dkk (2014). Pengaruh Penerimaan Pajak Daerah dan Retribusi Daerah terhadap Pendapatan Asli Daerah pada Kabupaten dan Kota di Provinsi Kalimantan Selatan. Jurnal Ekonomi dan Bisnis. Vol.07 No 01, STIE Nasional. Banjarmasin.

[6] Republik Indonesia. Undang-Undang Nomor 28 Tahun 2009 tentang Pajak Daerah dan Retribusi Daerah. Jakarta.

[7] Republik Indonesia. Undang-Undang Nomor 33 tahun 2004 tentang Perimbangan Keuangan antara Pusat dan Daerah. Jakarta.

[8] Sanusi, Anwar. (2011). Metode Penelitian Bisnis. Jakarta: Salemba Empat. 
[9] Lakoy, Toar Waraney., dkk. (2016). Kontribusi dan Pengaruh Penerimaan Retribusi Daerah Terhadap Pendapatan Asli Daerah di Kabupaten Minahasa Selatan. Jurnal Berkala Ilmiah Efisiensi. Vol.16 No.01, Fakultas Ekonomi dan Bisnis. Universitas Sam Ratulangi. Manado. 